\title{
Boosting City Image for Creation of a Certain City Brand
}

\author{
Ahmadreza Shirvani Dastgerdi ${ }^{\mathrm{A}^{*}}$, Giuseppe De LucaA \\ Received: January 10, 2019 | Revised: February 26, 2019 | Accepted: March 05, 2019
}

DOI: $10.5937 / g p 23-20141$

\begin{abstract}
Global cities are increasingly competing together in order to showcase themselves as the best destination for tourists, investors, and talented people. During the last four decades, there has been a growing interest in City branding. It takes place within a communication system that closely connects the overall city image and identity. Community leaders are more and more recognizing that there is a direct link between the city image and its attractiveness as a place to visit, live, invest, and study. Aimed at developing the theoretical framework of city branding, this research attempts to identify and explain the relationship between the variables affecting the city image as a paradigmatic model of city branding and sustainable urban development. Therefore, 35 peer-reviewed articles are initially selected from the $\mathrm{Di}$ rectory of Open Access Journals (DOAJ), through purposive sampling. Then, the collected data is analyzed in four stages using grounded theory. The results of this study indicate that the boosting of city image is a complex process that continuously and dynamically requires a meaningful combination of planning, actions, and stakeholders at various organizational levels.
\end{abstract}

Keywords: global city; city branding; city image; sustainable urban development

\section{Introduction}

A brand is not the product itself; it is what gives meaning and value to the product and defines its identity (Kapferer, 1992). It is a set of characteristics, mental images or feelings that consumers recall when they think of a specific symbol, product, service, organization or place (Kavaratzis \& Ashworth, 2005; Simeon, 2006). According to Kapferer (1997) brands are supposed to be the crux of transactions and exchanges between the consumers and the service providers. It represents the steps taken towards customer satisfaction or different elements of customer relationship management. He reminds us that "before knowing how we are perceived, we must know who we are" and thus, he suggests that brand identity must be established before one considers what brand image is or ought to be (Kapferer, 1999).
During the last four decades, there has been a growing interest in city branding within academia and the public authorities (Oguztimur \& Akturan, 2016). Given the globalization and the free movement of capital, goods, and people, through the city branding strategy, cities compete to each other not only as tourist destinations (Hanna \& Rowley, 2011) but also for the attraction of professional labor, residents and investors (Zenker \& Martin, 2011). City branding takes place within a communication system that closely connects the overall city image and identity (Kavaratzis, 2004; Kavaratzis \& Ashworth, 2005). Also, City branding may be considered innovation in the overlapping fields of marketing and communication (Popescu, 2017b). According to Ashworth (Ashworth, 2009), one of the objectives of city branding is to create uniqueness, which makes the city differentiable from others

\footnotetext{
A School of Urban and Regional Planning, University of Florence, Via Micheli 2, 50121, Florence

* Corresponding author: Ahmadreza Shirvani Dastgerdi; e-mail: ahmadreza.shirvanidastgerdi@unifi.it
} 
in the globalized world. It aims at attracting resources to the cities in a way that ensures the quality of place and wellbeing of the citizen (Björner, 2013; Popescu, 2017c). Baker (2007) has found that in city branding, the image and identity of a particular destination play an important role in making a city unique among various alternatives. Zhang and Zhao (2009) discussed that the main goal of city branding is to create a clear image of the city in the globalized world. Therefore, what should be noticed in the branding of a city is that "how culture and history, economic growth and social development, infrastructure and architecture, landscape and environment, etc. can be transformed into a justifiable identity which is acceptable to all people. Anholt (2016) indicates a set of factors, e.g. image, identity, places, the position of city, suitable location, capacity and vitality of people as prerequisites and variables affecting the city brand. Some scholars have mentioned these factors using titles such as cleanliness, safety, business opportunities, shopping centers, transportation, cultural activities, government services and social affairs (Merrilees et al., 2013).

Research has shown that the tendency of cities, regions, and countries to invest in branding campaigns is increasing with the aim of fame and competition in the global market (Oguztimur \& Akturan, 2016). Some studies also have highlighted the important role of branding in sustainable development (Dinnie, 2015; Maheshwari et al., 2011; Rehan, 2014). a key factor in the success or failure of city branding strategies is the identification of stakeholders and their accompaniment in the representation and formulation of a brand, which leads to an increased sense of ownership and sustainability of brand (Van Gelder, 2011). In general classification, key stakeholders of city branding in- clude entrepreneur groups, investors, local people and visitors (García et al., 2012).

Most public authorities and leaders have found that there is a direct link between the image of their city and its attractiveness as a place to travel, live, invest and study (Dinnie, 2010). According to Boyer (2011) Images of the city offered a sense of identity, well-being, and belonging. They formed the basis of memory systems; they attracted attention and made a place memorable, storable in the mind. The image of city can be considered as one of the most important key concerns both for city identity as well as city branding. City image can be best interpreted at the intersection of city branding and city identity since the image is an indispensable part of both (Riza et al, 2012). Also, some studies (Bigné et al., 2001; Hussein et al., 2018) confirm a positive relationship between image and satisfaction of visitors/tourists. However, the lack of proper understanding of factors affecting the city image and the interrelation between these factors sometimes cause urban managers and policymakers associated with social realms, investment, tourism, etc. to act without specific plans and strategies or, in some cases, take independent and even conflicting actions. Consequently, cities present uncoordinated, contradictory and chaotic images instead of a clear, bright and coherent image. This may cause many difficulties in branding or rebranding a city due to its long process and stakeholders involvement (Kulibanova \& Teor, 2017). Considering the significance of city image in the creation of a certain brand for the city, this study attempts to identify variables and explain the relationship between the variables affecting the city image as a paradigmatic model of city branding and urban sustainable development.

\section{Research Methodology}

\section{Method}

The grounded theory is the used method in this study. It is a systematic guideline for gathering and analysing data to generate middle-range theory (Charmaz \& Belgrave, 2007). This method is based on four stages of analysis, including codes, concepts, categories, and theory. There are three schemes for conducting the grounded theory research, i.e. systematic approach (Strauss \& Corbin, 1994), emergent approach (Glaser, 1992) and constructivist approach (Charmaz, 2006). A systematic approach is employed in this study.

\section{Sampling}

In this study, articles on city branding are analyzed through grounded theory method, which have been published in scientific journals since 2008. The purposive sampling method is used in this research. Therefore, the keywords "city branding" and "place branding" are firstly searched in the directory of open access journals (DOAJ) for purposive sampling. Then, articles focused on other subjects or presented at conferences are removed from the list. This evaluation is based on the title of the article, the abstract and the scope of the journal. Finally, 35 articles are selected from the whole 122 articles (Table 1). 
Table 1. The frequency of samples for each journal

\begin{tabular}{|c|c|c|}
\hline Codes & Papers & Journal Name \\
\hline 49 & 1 & Almatourism \\
\hline 17 & 1 & Anuário do Instituto de Geociências \\
\hline 80 & 6 & ArchNet- International Journal of Architectural Research \\
\hline 7 & 1 & Asian Journal of Behavioural Studies \\
\hline 22 & 1 & Baltic Region \\
\hline 29 & 2 & Ecoforum \\
\hline 12 & 1 & Economics \& Sociology \\
\hline 15 & 1 & Èkonomika Regiona \\
\hline 20 & 2 & Ekonomski Vjesnik \\
\hline 14 & 1 & HBRC Journal \\
\hline 11 & 1 & Journal of Studies and Research in Human Geography \\
\hline 3 & 1 & International Studies Interdisciplinary Political and Cultural Journal \\
\hline 9 & 1 & Journal of Indonesian Tourism and Development Studies \\
\hline 9 & 1 & Jurnal Bisnis dan Manajemen \\
\hline 11 & 2 & Management Science Letters \\
\hline 11 & 1 & PASOS Revista de Turismo y Patrimonio Cultural \\
\hline 11 & 2 & Problemi Ekonomik \\
\hline 20 & 1 & Regional Studies, Regional Science \\
\hline 8 & 2 & Revista de turism \\
\hline 16 & 1 & Spatium \\
\hline 6 & 2 & Sustainability \\
\hline 13 & 1 & Territorio della Ricerca \\
\hline 2 & 1 & Transylvanian Review of Administrative Sciences \\
\hline 7 & 1 & Turističko Poslovanje \\
\hline
\end{tabular}

\section{Results}

\section{Open coding}

Given the content analysis, 35 articles are firstly categorized into five groups (Figure 1): economic performance (5), advertising strategies (8), cultural activities (6), policy-making (2), and urban planning (14). At this stage, 403 codes are extracted and 65 concepts are derived by classifying the same codes. Subsequently, 17 categories are obtained through the classification of similar concepts (Table 2).

\section{Axial coding}

In the axial coding step, a logical relationship is established between the categories based on the general pattern known as the "research paradigm". Accordingly, the axial category is determined and the other categories are then related to it as secondary categories by different titles of the paradigm model (Figure 2).

\section{Economic performance}

The fact that global cities are in strong competition with each other for attracting resources and facili-

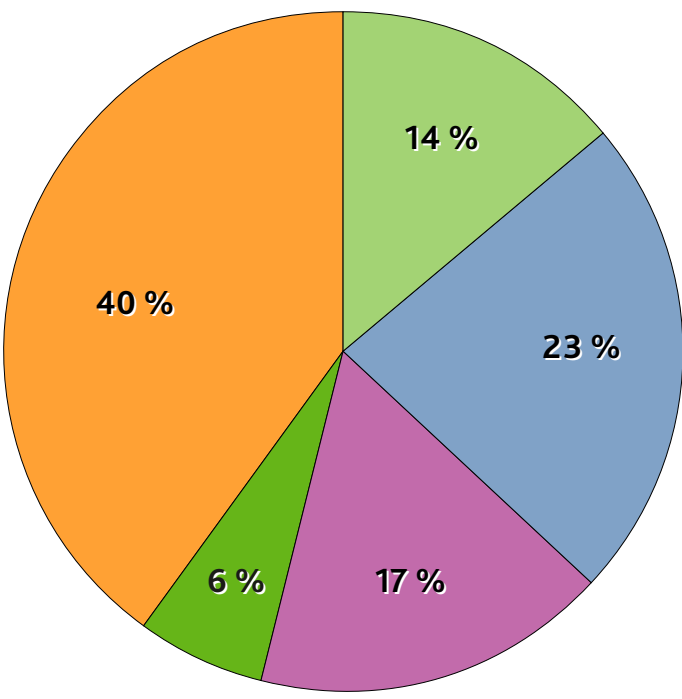

Economic performance Advertising strategies

Cultural activities Policy making Urban planning

Figure 1. Frequency chart and classification of samples based on content analysis 
ties has been noticed in many scientific studies. Some scholars even have gone beyond and referred to the competition between cities and countries. It can be argued that discussions on urban economics themselves are a reaction to the emergence of new competitive atmosphere between cities, which employs the city branding as an effective tool for differentiating and increasing the credibility of cities. Creating a unique image of the city, this tool tries to minimize the uncertainty in investment and connect the city to the global economy by financial and credit institutions around the world. This action spreads the activities associated with the global economy (e.g. tourism) in the host city. The prosperity of economic activities in the host city can increase the value added for properties, employment, income and tax levels that are effective in improving the quality of citizens' life. The results of Maastricht Treaty held in 1993 and the legal framework of European countries show that the world economy and the dependence of life and sustainable development of cities on it are so important that even geographic borders are neglected.

\section{Media and advertising}

Advertising, and media are a part of city branding process that shares the distinctive aspects and strategic objectives of the city. Advertising strategies along with executive management have a significant impact on the introduction of city and its competitive advantages. Associated with the participation and acceptance of stakeholders, advertising strategies are summarized in abstract terms of motto and logo of the city. Measures and evaluating of the effectiveness of advertising tools can be considered as one of the most important tasks of media management. These measures include a wide range of activities such as the development of technology to cover cultural-sports events, development of satellite networks and establishment of online advertising bases

Table 2. Extracted concepts and categories from the samples.

\begin{tabular}{|c|c|}
\hline Categories & Concepts \\
\hline $\begin{array}{l}\text { Economic } \\
\text { development }\end{array}$ & $\begin{array}{l}\text { Attraction of investors, elimination of geographical boundaries for economic purposes, brand as intangible asset, } \\
\text { competition between cities and countries }\end{array}$ \\
\hline $\begin{array}{l}\text { Competitive } \\
\text { advantage }\end{array}$ & $\begin{array}{l}\text { Improvement of quality of life, the knowledge-based economy with cultural and tourism activities, reduction of } \\
\text { uncertainty in decision-making for investment }\end{array}$ \\
\hline Global economy & $\begin{array}{l}\text { Hosting for world financial institutions, connection to the world economy, tourism capacities as a part of the } \\
\text { world economy }\end{array}$ \\
\hline Value-added & Enhancement of productive services, increased value of estates and capital, increase in taxes, business boom \\
\hline Advertising policies & Utilization of the media in city branding, constructive changes by cultural tools \\
\hline $\begin{array}{l}\text { Advertising } \\
\text { infrastructure }\end{array}$ & $\begin{array}{l}\text { Development of technology to cover cultural-sports events, development of satellite networks, establishment of } \\
\text { online advertising bases }\end{array}$ \\
\hline Advertising package & $\begin{array}{l}\text { Application of logo, suitable slogans, effective public relations, the illustration of the city as the best choice, } \\
\text { targeted advertising }\end{array}$ \\
\hline Competitive strategy & $\begin{array}{l}\text { Competition between cities in the world with different motives, the attraction of economic and social capital, } \\
\text { urban sustainable development }\end{array}$ \\
\hline $\begin{array}{l}\text { Domestic political } \\
\text { structure }\end{array}$ & $\begin{array}{l}\text { Type of political system, activity of cities under the supervision of national policies, city branding as public policy, } \\
\text { government participation in investment and city branding }\end{array}$ \\
\hline $\begin{array}{l}\text { Foreign political } \\
\text { structure }\end{array}$ & $\begin{array}{l}\text { Role of national brand index in attraction of resources, the impact of national identity on identity of cities, foreign } \\
\text { affairs, replacement of non-oil economy }\end{array}$ \\
\hline $\begin{array}{l}\text { Human development } \\
\text { of community }\end{array}$ & $\begin{array}{l}\text { Development of cultural policies, Promotion of level of education of citizens, competitive advantage of } \\
\text { universities, globalization of universities }\end{array}$ \\
\hline $\begin{array}{l}\text { Improvement of city } \\
\text { identity }\end{array}$ & $\begin{array}{l}\text { Detection of city differences, recognition of city identity, regeneration of cultural heritage, emphasis on city } \\
\text { landmarks }\end{array}$ \\
\hline $\begin{array}{l}\text { Improvement of image } \\
\text { of place }\end{array}$ & $\begin{array}{l}\text { Detection of strengths of place, recognition of residents' view about the city, recognition of visitors' view about } \\
\text { the city, participation of citizens in creation of an ideal city image }\end{array}$ \\
\hline Global events & $\begin{array}{l}\text { Targeted hosting for global events, events as cultural capital, partnership as sister cities and expansion of } \\
\text { international interactions }\end{array}$ \\
\hline $\begin{array}{l}\text { Management of city } \\
\text { brand }\end{array}$ & $\begin{array}{l}\text { Meaningful branding, dynamic brand management, proper identification of interest groups, decision-making } \\
\text { based on engagement of stakeholders, urban managers' stability in city branding objectives, connection between } \\
\text { political organizations }\end{array}$ \\
\hline $\begin{array}{l}\text { Strategic plan for city } \\
\text { branding }\end{array}$ & $\begin{array}{l}\text { Balance between global pressure and local needs, attention to city brand location, recognition of stakeholder } \\
\text { interests, utilization of stakeholder powers, recognition of identifying characteristics of city, promotion of sense } \\
\text { of belonging to the city brand }\end{array}$ \\
\hline $\begin{array}{l}\text { Management of urban } \\
\text { development projects }\end{array}$ & $\begin{array}{l}\text { Connection of construction projects for branding purposes, development of urban public spaces, development, } \\
\text { and renovation of urban infrastructure, inspiration from global tourism models }\end{array}$ \\
\hline
\end{tabular}




\section{Cultural activities}

Cultural activities and human development of the community is one of the imperatives for city branding. These policies should be aimed at raising the level of education of citizens. In this regard, some scholars noticed universities as a competitive advantage of the city and considered the positive role of the globalization of universities and the educational system in pursuit of city branding objectives. Moreover, global events are noticed as cultural capital, which remains in the memory of inhabitants even for a long time after the ending. The recognition of residents' view on the city is of great importance in terms of the cultural dimension in city branding. Therefore, in the first stage, it is necessary to recognize the identity of city and highlight its physical signs such as cultural heritage, landmarks, historical figures and, if no feature available, the implementation of enormous architectural projects. In cultural activities, the recognition of strengths of the place and participation of citizens in the creation of city image are mentioned as the main stage in the realization of a successful city brand.

\section{Policy-Making}

Although cities attempt to introduce themselves as the best choices, it should not be forgotten that policy-making is often based on national policies in cities. In fact, on a macro scale, the kind of ruling political system plays a major role in the realization of a city brand. Given the different motivations of cities in the creation of an image, the support of policymakers and participation of government in city branding projects are important for domestic policy-making. On the other hand, some studies were conducted about the effect of national identity on the identity of cities. And they referred to the significant role of the na- tional brand index in the attraction of resources from cities. Therefore, foreign policy-making and the communication and interaction of government with the world can be considered as effective factors in the realization of city brands.

\section{Urban Planning}

The meaningful brand and its acceptability are the most important goals of city branding. Hence the proper identification of interest groups, detection of interests of stakeholders and urban decision-making based on participation of stakeholders can guarantee the meaningfulness and acceptability of city brands. Considering the state and organizations as an interest group, urban management must try to come to an agreement among organizations by connecting the political institutions. Accordingly, urban managers should balance the global pressures and local needs, so that the stability of managers plays a key role in achieving the goals due to the long-term process of city branding. In this regard, urban development projects must be managed in order to always serve along the objectives of city brand and enhance the sense of belonging to the brand by creating a special image of the city.

\section{Objectives}

One of the important consequences of boosting city image is the promotion and improvement of position of city, which can be examined from various perspectives. Firstly, a city highly needs satisfied and active citizens in order to survive powerfully and progressively. Efforts to attract resources and enhance the identity of the place create a fascinating image of the city, which increases the citizens' satisfaction of the city. In return, these citizens create a stable identity

\begin{tabular}{|c|c|c|c|c|}
\hline $\begin{array}{l}\text { Economic } \\
\text { Performance }\end{array}$ & $\begin{array}{l}\text { Economic development, competitive advantage, } \\
\text { global economy, value added }\end{array}$ & & & 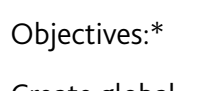 \\
\hline $\begin{array}{l}\text { Media and } \\
\text { advertising }\end{array}$ & $\begin{array}{l}\text { Advertising policies, Improvement of advertising } \\
\text { infrastructures, Development of promotional } \\
\text { and advertising package }\end{array}$ & & & $\begin{array}{l}\text { uniqueness, } \\
\text { Meaningful and } \\
\text { acceptability, }\end{array}$ \\
\hline $\begin{array}{l}\text { Cultural } \\
\text { Activities }\end{array}$ & $\begin{array}{l}\text { Human development of community, Improvement } \\
\text { of city identity, Improvement of image of place, } \\
\text { Global events }\end{array}$ & 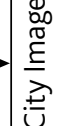 & 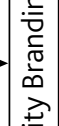 & $\begin{array}{l}\text { Justifiable } \\
\text { identity, }\end{array}$ \\
\hline $\begin{array}{l}\text { Policy } \\
\text { Making }\end{array}$ & $\begin{array}{l}\text { Competitive strategy, Domestic political structure, } \\
\text { Foreign political structure }\end{array}$ & & & $\begin{array}{l}\text { of stakeholders, } \\
\text { Attracting }\end{array}$ \\
\hline $\begin{array}{l}\text { Urban } \\
\text { Planning }\end{array}$ & $\begin{array}{l}\text { Brand strategic plans, Management of urban } \\
\text { development projects, City brand management }\end{array}$ & & & $\begin{array}{l}\text { Wellbeing } \\
\text { of citizens. }\end{array}$ \\
\hline
\end{tabular}

* Objectives are based on the literature review

Figure 2. Research paradigm model 
for the city, which is effective in improving the city image. Secondly, cities need to attract investment groups through their sustainable development. Cities which offer a justifiable identity and certain future and minimize the risk of investments are more successful in attracting the resources. Thirdly, the most important consequence of boosting city image is the increased number of domestic and foreign tourists in the operation phase of cities, which can help to turn the city into a potential destination for tourism, as confirmed by the results of this process in many cities around the world.

\section{Discussion}

Selective coding can be considered as the integrating and improving process of categories. In this stage, the theory is developed based on the results obtained from the previous two steps. At this level, it is attempted to propose a theory by bringing the categories together around an axial category and establish a systematic relationship between them.

City branding is focused on creating a distinctive and uniqueness identity, so that it can allocate more resources in competition with other cities and, thereby, promote the quality of citizens' life (Popescu, 2017a). Findings of this study suggest that although city image can be best interpreted at the intersection of city branding and city identity, it is influenced by a set of factors at higher levels that play a key role in its success or failure of city brand. In the process of boosting city image, what matters in the first step is a comprehensive understanding of the current city image. This image can be interpreted from the perspective of residents, domestic, and foreign. Some studies emphasize on the role of city image as the significant determinants of visit intentions (Shirvani Dastgerdi \& De Luca, 2018a) and tourist destination marketers' invest a great amount of resources to create a favorable and desirable image, which conquers potential travelers to visit or re-visit their destination (Martins, 2015; Shirvani Dastgerdi \& De Luca, 2018b). However, understanding residents' perceptions of tourism impacts and their level of support for its development is considered vital for the boosting city image (Stylidis, 2016). Therefore, the participation of these three groups in expressing their views on the city is very constructive and effective in determining the urban planning policies.

There is not just a single strategy for city branding because of the centrality of distinctions. These differences include a wide range of cultural, economic or political realms (Dumbraveanu, 2010). The findings show that the political structure of countries affects the formation of city images (Aysu, 2013). For instance, Barcelona and Budapest are among the cities that turned to successful examples of city branding in the world by bypassing the communist political regime. Brexit can be seen as another example of the dependence and subjugation of cities to a political system.
Great Britain leaves the EU, while London, the capital of Britain, overwhelmingly voted to remain in the EU (Menon \& Salter, 2016). On the other hand, since cities need massive investments in the improvement of their urban infrastructure to create their own brands, the role of government is of great importance as a supporter and investor in projects. Furthermore, the role of cultural activities in understanding the differences and shaping the identity and image of the city is considerable. Human development and enhancement of level of education in the community can enhance image of city and influence the success of a city brand, which is associated with the attraction of specialist forces and the globalization of universities (Rekettye \& Pozsgai, 2015). Another important step towards the formation of city image is targeted planning for holding the important cultural or sports events at regional to international levels or those related to the city branding objectives (Grichting, 2013).

It should be noted that the emergence and sustainability of a successful city brand is not achieved but by participation of residents and stakeholders. What matters for a meaningful city brand is its acceptance by the stakeholders. The proper identification of interest groups and planning based on interests and participation of stakeholders enhance the sense of belonging to the city brand. However, it is obvious that the higher the level of knowledge of stakeholders, the more productive participation emerges (Heshmati et al., 2016). Hence, this is associated with cultural and educational policies of the society. Moreover, if the range of partners in a place feel that they have been involved in shaping the message, they are more likely to vocalize and embody it (Houghton \& Stevens, 2010).

Boosting city image is a participative task, involving both the private and public sectors. The absence of such a participative approach risks the non-acceptability by public. Societal changes are often not discussed in the literature of city branding. The time element is very important because it highlights the fluctuating reality of society (Ooi, 2010, p. 61). Before the city branding process can begin, it is paramount to understand how the city sees itself and how it wants to be perceived externally. When multiple stakeholders are involved, this task can become 
complex (Lau \& Leung, 2011). The identity of the brand depends largely on the recognition of the participants and sense of belonging of all stakeholders involved in this brand.

From a city branding approach city's image may be effectively managed through analysis of the public image of the city or design of the urban landscape. In the process of boosting city image, urban planning must balance the globalization pressures and local needs. Considering a systemic approach to urban planning, development projects must be designed and arranged consistent with the objectives of city brand
(Grichting, 2013). What complicates the boosting city image process is the wide range of stakeholders and a common acceptability to city image. In the long term, economic changes at regional and international levels, on the one hand, and political changes at organizational and national levels, on the other hand, have a major impact on branding objectives (Kulibanova \& Teor, 2017). It is thus essential to recognise the city image to create a meaningful urban brand. The findings of this study suggest that the improvement of city image is a dynamic cycle that emanates from multidimensional variables (Figure 3 ).

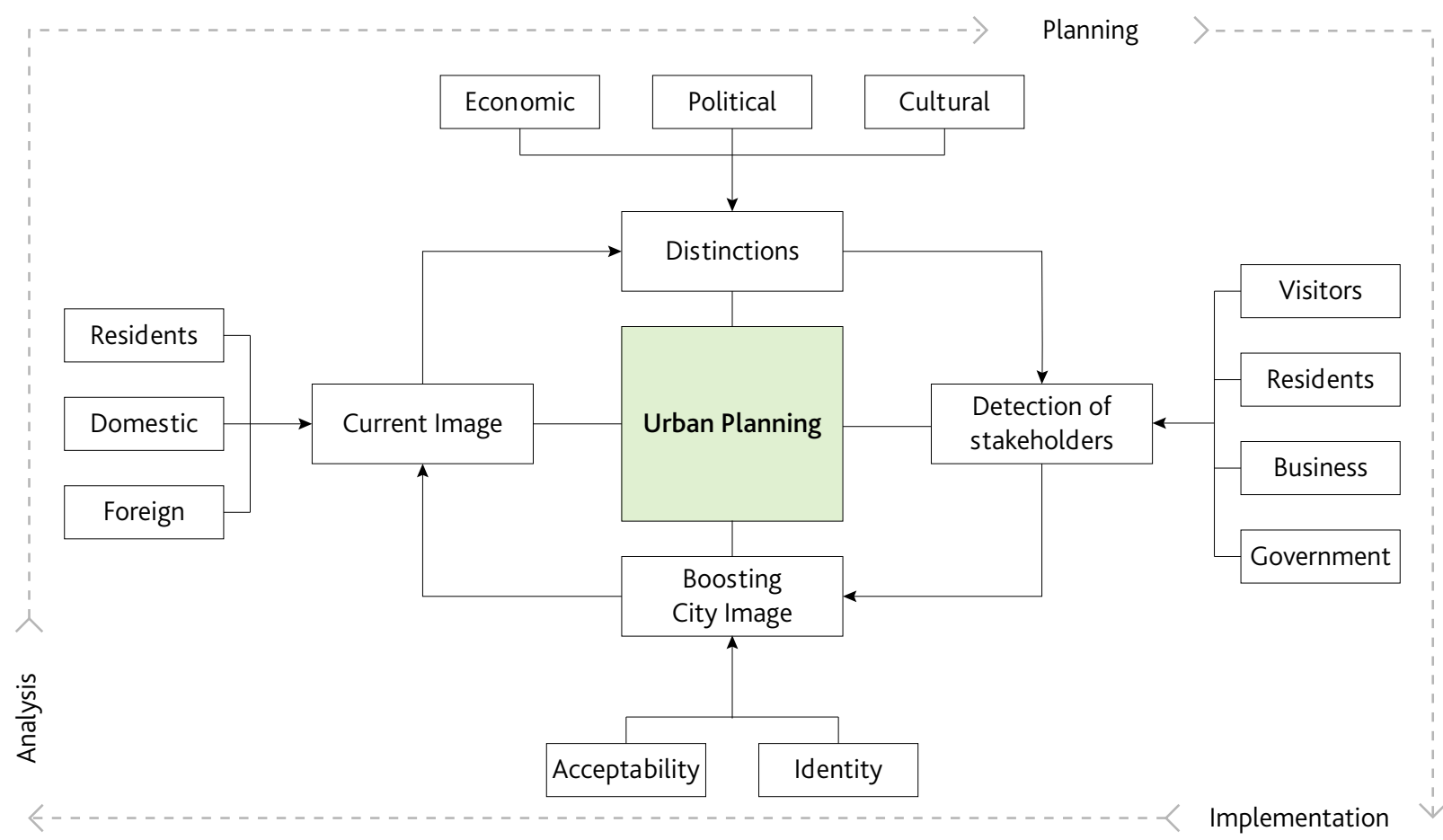

Figure 3. Cycle of effective factors in boosting city image

\section{Conclusion}

This study is conducted with the aim of identifying and explaining the relationship between the variables affecting the city image as a paradigmatic model of city branding and sustainable urban development using grounded theory. The result is interpreted as follows based on selective coding. Globalization and economic crises are phenomena that have increased the competition between cities in the attraction of resources. Struggles to create an ideal city image and sustainable development policies provide a basis for tendency towards city branding that is made by defining a unique identity accepted by the stakeholders. Although cultural activities have a constructive role in creating the city image and international mega events can bring unique opportunities to boost city image but will have limited effects unless followed by a longer-term strategy that links the city to its current social and economic environment, and to its own identities and core values; and perhaps most significantly, such mega-events must be endorsed by the people of the city themselves. Since communities change over the time, city image should be continually reviewed and strengthened. In creation of a certain and city brand, urban planning requires pay a special attention to activities that boost the image of a competitive city in terms of human health, quality of life, job creation, building public spaces and environmental innovations. In addition, proper identification of stakeholders and developing a sufficient participatory and communication approach guarantees the acceptability of city brand. This process occurs in a complex and 
multidimensional environment, in which many stakeholders participate through a variety of goals, motives, and interests. These variables affect the formation, rate of changes and realization or immaturity of creation of the city image. In addition, boosting city image is a dynamic and complex process that displays a meaningful mix of structure, activities, and participation of stakeholders continuously and dynamically. Therefore, creation of a certain city brand as a long-term strategy should be implemented base on a proper understanding of city image and its indicators in terms of economic, advertising strategies, cultural activities, policy-making and urban planning; involving both the private and public sectors.

\section{Acknowledgments}

This work was supported by a research grant (Number 1523274135) from the Ministry of Foreign Affairs and International Cooperation of Italy (ministero degli affari esteri e della cooperazione internazionale).

\section{References}

Anholt, S. (2016). Places: Identity, image and reputation. Springer. https://doi.org/10.1007/978-0-23027149-4

Ashworth, G. J. (2009). The instruments of place branding: How is it done? European Spatial Research and Policy, 16(1), 9-22. https://doi.org/10.2478/v10105009-0001-9

Aysu, G. Ç. (2013). Managing the image of cities in the "global village" city branding as an opportunity against globalization. Archnet-IJAR, 7(2), 258-268. https://doi.org/http://dx.doi.org/10.26687/archnetijar.v7i2.169

Baker, B. (2007). Destination branding for small cities: The essentials for successful place branding. Destination Branding Book.

Bigné, J. E., Sánchez, M. I., \& Sánchez, J. (2001). Tourism image, evaluation variables and after purchase behaviour: inter-relationship. Tourism management, 22(6), 607-616. https://doi.org/10.1016/So2615177(01)00035-8

Björner, E. (2013). International positioning through online city branding: The case of Chengdu. Journal of Place Management and Development, 6(3), 203226. https://doi.org/10.1108/JPMD-03-2013-0006

Boyer, M. C. (2011). The two orders of cybernetics in urban form and design. In Companion to urban design. Routledge. pp. 89-102.

Charmaz, K. (2006). Constructing grounded theory: A practical guide through qualitative research. London: Sage.

Charmaz, K., \& Belgrave, L. L. (2007). Grounded theory. The Blackwell Encyclopedia of Sociology. Wiley.

Dinnie, K. (2010). City Branding. In K. Dinnie (Ed.), City Branding: Theory and Cases. London: Palgrave Macmillan. https://doi.org/10.1057/9780230294790

Dinnie, K. (2015). Nation branding: Concepts, issues, practice. Routledge.
Dumbraveanu, D. (2010). Place branding: a challenging process for Bucharest the capital city of Romania. Human Geographies, 4(2), 53.

García, J. A., Gómez, M., \& Molina, A. (2012). A destination-branding model: An empirical analysis based on stakeholders. Tourism Management, 33(3), 646661. https://doi.org/10.1016/j.tourman.2011.07.006

Glaser, B. G. (1992). Basics of grounded theory analysis: Emergence vs forcing. Sociology press.

Grichting, A. (2013). Scales of flows: Qatar and the urban legacies of mega events. International Journal of Architectural Research, 7(2), 173-191.

Hanna, S., \& Rowley, J. (2011). Towards a strategic place brand-management model. Journal of Marketing Management, 27(5-6), 458-476. https:/doi. org/10.1080/02672571003683797

Heshmati, F., Hosseini, T., \& Keyvan, Y. (2016). The role of citizenship education in development of urban branding. Management Science Letters, 6(6), 409-412.

Houghton, J. P., \& Stevens, A. (2010). City branding and stakeholder engagement. In K. Dinnie (Ed.), City Branding: Theory and Cases. London: Palgrave Macmillan. https://doi.org/10.1057/9780230294790

Hussein, A. S., Troena, E. A., \& Mujihestia, T. I. (2018). The role of city image and visitors' satisfaction on visitors' revisit intention: a study in an enclave city. Jurnal Aplikasi Manajemen, 16(2), 309-320. https:// doi.org/10.21776/ub.jam.2018.016.02.14

Kapferer, J. N. (1992). Strategic Brand Management: New Approaches to Creating and Evaluating Brand Equity. London: Kogan Page.

Kapferer, J. N. (1999). Strategic Brand Management. London: Kogan Page.

Kavaratzis, M. (2004). From city marketing to city branding: Towards a theoretical framework for developing city brands. Place branding, 1(1), 58-73.

Kavaratzis, M., \& Ashworth, G. (2005). City branding: An effective assertion of identity or a transi- 
tory marketing trick? Tijdschrift Voor Economische En Sociale Eografie, 96(5), 506-514.

Kulibanova, V. V., \& Teor, T. R. (2017). Identifying Key Stakeholder Groups for Implementing a Place Branding Policy in Saint Petersburg. Baltic Region, 9(3), 99-115. https://doi.org/10.5922/2079-8555-20173-7

Lau, F., \& Leung, A. (2011). Chongqing's City Branding. In K. Dinnie (Ed.), City Branding: Theory and Cases. London: Palgrave Macmillan.

Maheshwari, V., Vandewalle, I., \& Bamber, D. (2011). Place branding's role in sustainable development. Journal of Place Management and Development, 4(2), 198-213. https://doi.org/10.1108/17538331111153188

Martins, M. (2015). The tourist imagery, the destination image and the brand image. Journal of Tourism and Hospitality Management, 3(2), 1-14.

Menon, A., \& Salter, J. P. (2016). Brexit: Initial reflections. International Affairs, 92(6), 1297-1318. https:// doi.org/10.1111/1468-2346.12745

Merrilees, B., Miller, D., \& Herington, C. (2013). City branding: A facilitating framework for stressed satellite cities. Journal of Business Research, 66(1), 3744. https://doi.org/10.1016/j.jbusres.2011.07.021

Oguztimur, S., \& Akturan, U. (2016). Synthesis of City Branding Literature (1988-2014) as a Research Domain. International Journal of Tourism Research, 18(4), 357-372. https://doi.org/10.1002/jtr.2054

Ooi, C. S. (2011). Paradoxes of city branding and societal changes. In K. Dinnie (Ed.), City Branding: Theory and Cases. London: Palgrave Macmillan.

Popescu, G. V. (2017a). From local to global with city branding. Ecoforum Journal, 6(1), 10.

Popescu, G. V. (2017b). Innovation Perspectives in Local Administration at the Beginning of the "Age of Cities." Management Dynamics in the Knowledge Economy, 5(2), 175-201https://doi.org/10.25019/mdke/5.2.02

Popescu, G. V. (2017c). Sibiu between european capital of culture and brexit: city brand perspective on citizens. Ecoforum Journal, 6(3), 8.

Rehan, R. M. (2014). Urban branding as an effective sustainability tool in urban development. HBRC
Journal, 10(2), 222-230. https://doi.org/10.1016/j. hbrcj.2013.11.007

Rekettye, G., \& Pozsgai, G. (2015). University and Place Branding: the Case of Universities Located in ECC (European Capital of Culture) Cities. Ekonomski Vjesnik: Review of Contemporary Entrepreneurship, Business, and Economic Issues, S(28), 13-24. https:// doi.org/10.1108/IJEM-10-2016-0212

Riza, M., Doratli, N., \& Fasli, M. (2012). City Branding and Identity. Procedia - Social and Behavioral Sciences. https://doi.org/10.1016/j.sbspro.2012.02.091 Shirvani Dastgerdi, A., \& De Luca, G. (2018a). Specifying the Significance of Historic Sites in Heritage Planning. Conservation Science in Cultural Heritage, (18).

Shirvani Dastgerdi, A., \& De Luca, G. (2018b). The Riddles of Historic Urban Quarters Inscription on the UNESCO World Heritage List. International Journal of Architectural Research, 12(1), 152-163. https://doi.org/10.26687/archnet-ijar.v12i1.1315

Simeon, R. (2006). A conceptual model linking brand building strategies and Japanese popular culture. Marketing Intelligence and Planning, 24(5), 463-476. https://doi.org/10.1108/o2634500610682863

Strauss, A., \& Corbin, J. (1994). Grounded theory methodology. Handbook of Qualitative Research, 17, 273-285.

Stylidis, D. (2016). The Role of Place Image Dimensions in Residents' Support for Tourism Development. International Journal of Tourism Research, 18(2), 129-139. https://doi.org/10.1002/jtr.2039

Van Gelder, S. (2011). City brand partnerships. In K. Dinnie (Ed.), City Branding: Theory and Cases. London: Palgrave Macmillan.

Zenker, S., \& Martin, N. (2011). Measuring success in place marketing and branding. Place Branding and Public Diplomacy, 7(1), 32-41. https://doi. org/10.1057/pb.2011.5

Zhang, L., \& Zhao, S. X. (2009). City branding and the Olympic effect: A case study of Beijing. Cities, 26(5), 245-254. https://doi.org/10.1016/j.cities.2009.05.002 